\title{
Book Review: Exiting The Short Bus
}

Jack Fellows Crews, Ed.D, University of Phoenix, USA

\begin{abstract}
$\mathrm{t}$ is comforting and reassuring to know that those in an organization you are working with have compassion for one another and their environment. It is so difficult to function if others do not comprehend your situation.
\end{abstract}

In the short bus (the short bus is the one that in most school districts transports those students with specialneeds); it may seem like a chaotic and confusing group of people that have individual needs and no compassion for each other. However, what is occurring in this bus is no different from the activities in the big bus. To have compassion for all those in the short bus is to offer a support that is always appreciated but many times not communicated. It is sometimes difficult to express one's endorsement of this group of students, but it elicits a positive feeling and a good atmosphere. The short bus has a culture that is unique in appearance, but it is essentially the same as that of the big bus.

The major difference between those in the short bus and those that are not is that they are viewed from the outside as different, so they are not well accepted and are often avoided. With this onus being laid on those short bus people, in tandem with the burden of a disability, the student develops a unique type of self-acceptance or self-denial. Whatever the term or the definition, these folks are coming into this world with an enormous weight on their shoulders.

We that are without this obstruction seem to be able to justify our actions of avoidance without guilt or thought. We do not need to ride in the short bus, thus we are immune from any activity that would include those students. If they are included in a class designed for socialization for a short while, this is to be tolerated, however, to be included by mandate for socialization almost seems to be an oxymoron, as one in that situation would find the socialization to be moot due to the mandate.

Current reform efforts in special education are demanding an increase in the inclusion of students with special needs in general education classes and in state- and district-wide standardized assessment (Heumann, 2000). This suggests that special education as a field needs to address problems of program coherence and program options before it can solve the problems of poor test scores and poor academic outcomes.

Some research suggests that educators need to consider their impact on students. The comments suggested they must take into account the perceptions of students. Nearly three-fourths of the youth provided at least one response suggesting educators change their behavior or attitude. The comments appear to represent distinct calls for changes that could be readily carried out at little cost. For instance, high school settings could be restructured to encourage teachers and administrators to have more positive encounters with youth in special education. Moreover, such requests seem reasonable if society wants to keep these youth in school until they can graduate. The suggestions reinforces earlier research that suggest the need to help youth to bond with the school setting (Finn, 1989; Wehlage,1983 as cited in Kortering, 1999), get educators to be more responsive to youth (Goodlad,1984; Hamilton \& Hamilton,1992; Natriello, Pallas, \& McDill, 1986; Wehlage \& Rutter, 1986 as cited in Kortering, 1999), reduce student frustration or alienation (Finn,1989; Newmann,1981 as cited in Kortering,1999), facilitate youth success feelings (Livingston, 1959 as cited in Kortering, 1999), and display more care toward youth (Mann, 1986 as cited in Kortering, 1999). A related finding was that only five $(11 \%)$ youth indicated that they even talked to teachers or administrators about dropping out of school, whereas nearly half reported talking to a friend or parent. These suggestions cut to the heart of a profession that purports to provide specially designed instruction tailored to the unique needs (many of which may be emotional) of individual learners.

Vygotsky believed that a physical or mental impairment could be overcome by creating alternative but equivalent roads for cultural development. Common laws of development for children with disabilities and their no disabled peers include internalization of the external cultural activities into internal processes via psychological tools 
and mediated learning provided by adults. The concept of the internalization of psychological tools as the main mechanism of development has a special importance for rehabilitation in the field of special education. Different tools (e.g., various means of communication) may convey essentially the same educational information and the same meaning. Vygotsky (1983) said, "Different symbolic systems correspond to one and the same content of education.... Meaning is more important than the sign. Let us change signs but retain meaning".

An organic defect is recognized by society as a social abnormality in behavior. Expectations and attitudes of social milieu and conditions created by the society influence the access of a child with disability to sociocultural knowledge, experiences, and opportunity to acquire psychological tools. Changing negative societal attitudes toward individuals with disabilities should be one of the goals of special educators (Vygotsky, 1995 as cited in Gindis, 1999).

There are many strategies teachers can use to increase peer acceptance of children with disabilities. Some of these strategies can be found is in the introductory texts used in teacher education courses (Salend, 1994 as cited in Smoot 1994). For example, teachers can give older students information about varying types of disabilities prior to the arrival of students with special needs in the general education class. Students can be taught preferred ways of interacting positively with others with specific disabilities (Chalmers and Faliede, 1997 as cited in Smoot, 2004) The arts can be used to help students empathize with others who look or act differently. Special activities can be conducted as introductions and get-acquainted mixers. Within the general education class, teachers can include the student with special needs in collaborative group activities or communication exercises (Salend, 1994 as cited in Smoot 1994). Many of these strategies work well in improving peer acceptance of students with various disabilities and they are not difficult or expensive to implement.

The number of students with disabilities pursuing a post-secondary education is increasing. Data indicates that freshmen who reported having a disability is increasing, the increase in students with disabilities seeking a postsecondary education probably will result in more requests for accommodations. In accommodating special-needs students in post-secondary education, it is important for all parties to understand that the laws governing students with disabilities in high school are different from the laws that apply to these students in post-secondary education. By understanding these differences, secondary-school educators will be able to create more appropriate Individual Education Programs (IEPs) to assist the student with disabilities in his or her transition to higher education.

Despite the fact that the educational policy of inclusion affects all involved, special-needs students in one study showed significantly more positive attitudes toward the concepts of inclusion and equifinality (a student-centered approach to the concept of inclusion), than both their own parents, as well as the regular classroom students and their parents. It was as if these special-needs students considered themselves to be at the forefront of the whole issue of inclusion. They professed to like the policy of inclusion more than their parents and their regular classroom counterparts. All of these factors seem to indicate that special-needs students have come of age. It seems they have just broken out of the closet of segregation that has confined them for decades. Now they want to be noticed, and they want alternative educational policies that suit them best. They are ready to embrace anything new and promising.

The equal-outcome, student-centered approach has been welcomed, albeit a bit cautiously. Perhaps something too good to be true has too much of a dream-like characteristic that is hard to fathom for the moment.

The debate of total inclusion versus total exclusion may not be resolved by a dichotomous decision which strictly endorses only one of these two extremes. Perhaps it can be resolved by adopting a policy that optimizes the outcome of each special-needs student, given their needs. It is time for us to dispose of the dichotomous inclusion/exclusion frame of thinking and view the issue of integration on a continuum upon which placement of students is based on the criterion of student-centered equifinality.

Inclusion may not be the answer, but, according to one study, it has promising beginnings to help with the integration of those with special needs. 


\section{REFERENCES}

1. Field, S., \& Hoffman, A. (1994). Development of a model for self-determination. Career Development for Exceptional Individuals; 17, 159-169.

2. Gilbert, P. (1984) Depression: From Psychology to Brain State. London: Lawrence Erlbaum Associates.

3. Gindis, B. (Nov/Dec. 1999). Vygotsky's Vision: Reshaping the Practice of Special Education for the $21^{\text {st }}$ Century. Remedial \& Special Education; 20(6) 333-341.

4. Kleck,R. (1966). Emotional arousal in interaction with stigmatized persons. Psychological Reports,19, 1226

5. Hoffman, A. (2003). Teacher decision making to students with learning disabilities by promoting selfdetermination. ERIC Digest ED 481859 ERIC Clearinghouse on Disabilities and Gifted Education.

6. Heumann, J.E. (2000). Assistant Secretary for Special Education and Rehabilitative Services Hearing Before the House Subcommittee on Oversight and Investigations Hearing on "Behavioral Drugs in Schools: Questions and Concerns.

7. Korteroing, L. J. (March/April 1999). School dropout from the perspective of former students: Implications for secondary special education programs. Remedial and Special Education; 20(2) 78-84, 1 chart.

8. Mithaug,\& Vitello J. (2001). Inclusive schooling: National and international perspectives. Remedial and Special Education, 22(4) 194-213 DOI: 10.1177/074193250102200401

9. Pugach \& Warger. (2001). Curriculum matters: Raising expectations for students with disabilities. Remedial and Special Education, 22(4), 194-213 DOI: 10.1177/074193250102200401

Markovchick, P. (Dec. 1996). Cooperative learning and peer acceptance of students with learning disabilities. Journal of Social Psychology; 136(6), 741-752, 3 charts.

10. Smoot, S.L. (Summer, 2004). An outcome measure for social goals of inclusion. Rural Special Education Quarterly; 23(3) 15-22, 2charts, 2 diagrams.

11. Wehmeyer, M. (200). Self-determination and the education of students with disabilites. ERIC EC Digest \#E632. Arlington, VA:ERIC Clearinghouse on Disabilities and Gifted Education

12. Whelton, W.J. \& Greenberg, L.S. (2005). Emotion in self-criticism. Personality and Individual Differences, $38,1583-1595$. 


\section{NOTES}

